\title{
VONIS MUI UNTUK ALIRAN SEMPALAN
}

\author{
Kamarusdiana
}

Judul Buku : Argumen Fatwa MUI tentang Kelompok dan Paham Menyimpang 1994-2011 (Perspektif Hukum Islam dan Hak Asasi Manusia)

Penulis : Zainul Mun'im

Penerbit : Cinta Buku Media

Tahun Terbit : Juni, 2016

Tebal : $\mathrm{x}+286$ Halaman

Majelis Ulama Indonesia (MUI) memiliki peran strategis dalam kehidupan keberagamaan di Indonesia, khususnya umat Islam. Sebagai lembaga keagamaan, MUI cukup memberikan pengaruh yang kuat bagi masyarakat Muslim. Hal ini yang terkait dengan otoritas MUI dalam mengeluarkan fatwa-fatwa, baik berupa persoalan aqidah hingga mualamah sekalipun. Lahirnya fatwa-fatwa tersebut dalam beberapa kesempatan cukup memberikan kontroversi tersendiri didalam masyarakat, sehingga ketegangan sosialpun kerap kali terjadi dalam merespon fatwa dari MUI.

Sebagai wadah para cendekiawan muslim, peran MUI menjadi penting sebagaimana eksistensi organisasi Nahdlatul Ulama dan Muhammadiyah yang menjadi poros diskursus keIslaman saat ini, meskipun ada yang mencitrakan MUI sebagai organisasi kepanjangan pemerintah atau Negara.

Atas dasar itu, dalam buku ini akan menjelaskan mengenai fatwa-fatwa yang dikeluarkan oleh MUI. Hanya saja tidak menyeluruh pada fatwa-fatwa yang telah ada. Fatwa yang akan dikaji dalam buku ini hanya sebatas pada fatwa seputar isu-isu kebebasan beragama dan berkeyakinan dalam sudut pandang hak asasi manusia (HAM). Karena memang secara tidak langsung lahirnya fatwa yang bernuansa kebebasan beragama dan berkeyakinan cukup memberikan citra eklusif dalam beragama. Hal itu yang menjadikan banyak menimbulkan kontroversi sosial. Bahkan, tidak sedikit masyarakat yang tidak terkendali dalam merespon fatwa tersebut, sehingga yang terjadi kemudian adalah tindak kekerasan atas nama agama.

Perlu diketahui bahwa lahirnya fatwa-fatwa tersebut tidak serta-merta begitu saja, melainkan adanya suatu peristiwa yang terjadi dan berkaitan dengan sosial-keagamaan, di mana MUI sebagai lembaga keagamaan dengan 
otoritas tersendiri dirasa perlu untuk mengeluarkan fatwa. Setidaknya fatwa dari MUI dapat dijadikan rujukan, sehingga meredam suasana ketegangan yang ada atas suatu peristiwa.

Buku ini memiliki distingsi tersendiri dibandingkan dengan studi-studi yang telah ada sebelumnya. Pada studi-studi sebelumnya, tidak sedikit yang hanya terfokus pada proses dan respon atas fatwa yang dikeluarkan oleh MUI. Esensi alasan dikeluarkannya fatwa yang bernuansa HAM tidak banyak dibahas dalam studi-studi sebelumnya. Buku ini mencoba menggali adanya alasan instrumen HAM sebagai unsur lahirnya fatwa, khususnya yang berkaitan dengan hak kebebasan beragama dan berkeyakinan.

Dalam pandangan masyarakat umum, HAM merupakan hak yang bersifat natural (natural right) yang secara alami ada sejak manusia itu lahir, termasuk pula didalamnya hak kebebasan beragama dan berkeyakinan. Pandangan umum ini berdasarkan pada universalisme moral, di mana telah menjadi landasan utama natural right. Atas dasar itu, HAM sebagai moral bersifat universal (umum) dan tidak dapat dibatasi dengan perbedaan budaya dan tempat.

Namun, pandangan umum itu justru berbeda dengan pandangan MUI mengenai HAM. Dalam buku ini dielaborasikan bahwa MUI menganggap HAM sebagai bentuk representasi dari relativisme moral. Artinya, MUI tidak sependapat dengan pandangan umum bahwa HAM merupakan hak yang natural. Menurut MUI, HAM hanya sebatas pengakuan budaya dan moral yang bersifat relatif. Cara pandang MUI dalam melihat HAM cukup jelas pemaparannya dalam buku ini.

Studi atas fatwa MUI dalam buku ini berkaitan dengan enam fatwa tentang hak kebebasan beragama dan berkeyakinan dalam periodisasi waktu tahun 1994-2011, yakni; 1) fatwa tentang kelompok Inkar Sunnah (1994); 2) fatwa tentang kelompok Darul Arqam (1994); 3) kelompok tentang Eden Salamullah (1997); 4) fatwa tentang kelompok Ahmadiyah (2005); 5) fatwa tentang paham pluralisme agama (2005); dan 6) fatwa tentang kelompok alQiyadah al-Islamiyah (2007).

Temuan dalam buku ini tentang keenam fatwa tersebut menunjukkan bahwa MUI dalam mengeluarkan fatwa mempertimbangan unsur HAM didalamya. Meski tidak dijelaskan secara eksplisit dalam kerangka keenam fatwa tersebut. Argumen HAM yang digunakan oleh MUI lebih cenderung pada pertimbangan unsur ketertiban umum atau ketertiban sosial. Analisa ini 
dapat dipahami bahwa kelompok yang memiliki paham menyimpang dari Alquran dan Sunnah, maka dianggap mengganggu ketertiban umum.

Selain itu, buku ini menjelaskan secara lebih jauh bahwa MUI tidak hanya mengeluarkan fatwa tersebut, tetapi juga memberikan rekomendasi bagi pemerintah untuk melakukan pelarangan atas paham yang menyimpang dari Alquran dan Sunnah. Dari sinilah yang kemudian terdapat masyarakat yang merespon fatwa secara tidak terkendali, sebagaimana dipaparkan di atas.

Dijelaskan secara ekplisit dalam buku ini bahwa MUI dalam menerbitkan suatu fatwa tentang aliran dan paham tertentu yang diduga menyimpang dari Alquran dan Sunnah, MUI melakukannya hanya cukup melihat dan menyesuaikan keyakinan kelompok tersebut dengan ajaran dan kandungan yang ada didalam Alquran dan Sunnah, serta disertai dengan konsensus ulama (ijma'). Hal ini tentu sangat berbeda dengan fatwa dalam bidang ibadah dan sosial-budaya lainnya, di mana MUI tidak hanya merujuk pada Alquran dan Sunnah, melainkan menggunakan kaidah fiqih dan metode ushul fiqih lainnya. Dapat disimpulkan argumen MUI dalam fatwa tentang aliran dan paham menyimpang cukup bersifat normatif.

Pada dasarnya apa yang dipaparkan dalam buku ini cukup memberikan kejelasan. Dari segi sistematika, buku ini memiliki struktur yang baik dengan pembagian VI bab, satu bab pendahuluan, dua bab tentang kajian teori yang berkaitan dan berimbang, dua bab analisa pembahasan, serta satu bab penutup. Oleh sebab itu, tidak menyulitkan bagi pembaca saat melakukan analisa bacaan. Selain itu, pembaca akan lebih mudah mengikuti alur pemikiran yang ada didalam buku ini.

Penulis buku ini memiliki citra distingsi pemikiran tersendiri untuk studi-studi yang sejenisnya. Gagasan yang dibawa dalam buku ini cenderung menarik dalam studi akademik. Apalagi trend yang ada saat ini tentang aliran dan paham menyimpang cukup kuat didalam masyarakat. Setidaknya buku ini yang merupakan hasil tesis dapat memberikan arah rekomendasi atas maraknya aliran dan paham menyimpang.

Disisi lain, penggunaan instrumen HAM dalam buku ini juga menjadi daya tarik tersendiri. Artinya, sebagaimana dipaparkan di atas, selama ini studi-studi sebelumnya tidak menempatkan instrumen HAM dalam penelitiannya. Penggunaan instrumen HAM menunjukkan nilai-nilai 
humanisasi sangat menjadi prioritas dalam buku ini, sehingga penelitian yang sejenisnya diharapkan dapat menggunakan instrumen ini.

Dari segi pembahasannya, buku ini cocok untuk studi-studi akedemik di lingkungan kampus atau bagi para peneliti, sehingga buku ini kurang cocok untuk konsumsi khalayak publik. Hal itu dikarenakan akan terdapat kekhawatiran dispersepsi pembaca jika dibaca di luar studi akademik. Artinya, buku ini tidak direkomendasikan bagi khalayak publik di luar studi akademik.

Dari segi penggunaan tata bahasa, tidak sedikit akan membuat kesulitan pembaca dalam memahaminya. Hal itu dikarenakan sering kali terjadi pengulangan penggunaan bahasa, serta penggunaan susunan bahasa yang terlalu rumit, sehingga sulit untuk dipahami. Oleh sebab itu, untuk dapat memahami buku ini sering kali harus membaca berulang kali.

Sebagai buku untuk studi akademik, buku ini memang cukup bagus untuk dikaji lebih dalam. Hanya saja terdapat kekurangan akademik dalam buku ini. Penulis buku ini terlalu fokus pada studi HAM masyarakat umum, tanpa mempertimbangan nasib HAM atas pelaku aliran dan paham menyimpang. Penjelasan buku ini hanya sebatas pada fatwa MUI lahir atas terancamnya ketertiban umum. Padahal pasca fatwa MUI keluar justru HAM pemeluk aliran dan paham menyimpang menjadi sangat terancam. Karena pada realitanya memang pemeluk aliran dan paham menyimpang sering kali menjadi korban kekerasan atas nama agama. Hal inilah yang tidak dipaparkan oleh penulis buku ini. Padahal akan lebih menarik lagi jika instrumennya ditambahkan dengan hal itu. Setidaknya lewat buku ini, harapannya dapat memberikan penelitian baru akan diskurusus HAM untuk melengkapi kekurangan dalam buku ini. 